\title{
As "Cartas Chilenas" do jornal Minerva Brasiliense e a murmuração da Corte no Segundo Reinado
}

\author{
Socorro de Fátima Pacífico Barbosa*
}

\begin{abstract}
A tarefa precípua do historiador é estar atento às peculiaridades, é dialogar intensamente com suas fontes, sem cometer os equívocos gêmeos de tomalas ingenuamente pelo seu valor de face e de imporlhes uma gaiola de ferro de conceitos e teorias.
\end{abstract}

José Murilo de Carvalho

Este trabalho dá continuidade a outro, publicado na revista Veredas, intitulado "A epístola a Critilo e a murmuração da Corte no primeiro Reinado" (BARBosA, 2013), que demonstrou ser "A Epístola a Critilo", publicada no fornal Científico, Econômico, e Literário, ou Coleção de Várias Peças, Memórias, Relações, Viagens, Poesias, e Anedotas, em 1826, uma sátira que visa corrigir o comportamento obsceno do Imperador, D. Pedro I. Seguindo os caminhos abertos por esse trabalho, demonstro como as Cartas chilenas, publicadas no número 8 do jornal carioca $\mathrm{Mi}$ nerva Brasiliense Biblioteca Brasílica, são epístolas escritas pelo chileno Santiago Nunes Ribeiro, ${ }^{1}$ que assina a nota de rodapé da publicação, e tratam das desven-

Doutora em Literatura Brasileira e professora da Universidade Federal da Paraíba (UFPB), Joao Pessoa, PB, Brasil. E-mail: socorrofpb@yahoo.com.br

1 Santiago Nunes Ribeiro, natural do Chile, faleceu ainda muito moço na cidade do Rio Preto, em Minas Gerais, a 24 de dezembro de 1847, sendo lente de retórica e poética no Colégio Pedro II e lente de filosofia no Ateneu Fluminense, fundado em 1844, sócio e secretário do Instituto Histórico e Geográfico Brasileiro. Veio para o Brasil, ainda criança, com um tio e preceptor, em consequência de convulsões políticas que agitavam aquela república; mas em breve ele, que já era órfão de pais, viu-se órfão do único benfeitor, esse tio que era um clérigo virtuoso e ilustrado, e então procurou no comércio modesto emprego de caixeiro de balcão, no qual passou os primeiros anos da juventude; mas mesmo no balcão completou os estudos, que já tinha iniciado, de línguas mortas e vivas, e deu-se ao estudo dos poetas, dos filósofos e dos historiadores. Era isto na cidade da Paraíba, província do Rio de Janeiro e lugar pequeno para suas grandes, mas nobres ambições de saber, de instruir-se, o que o levou a passar à Corte, ocupando-se em leccionar particularmente e depois em colégios. Foi um dos fundadores da Minerva Brasiliense, fornal de Ciências, Letras e Artes, publicado por uma associação de homens de letras (Rio de Janeiro, 1843-1844, três volumes). Neste jornal, em que colaboraram Salles Torres Homem, Januário da Cunha Barbosa, Dr. Domingos de Magalhães, Dr. Emilio Maia, Dr. P. de Alcântara. Delegardes, Joaquim Norberto, Araújo Porto-Alegre e outros vultos da época, além de outros trabalhos, escreveu: i) A nacionalidade da literatura brasileira - no tomo 1, 1843-1844, p. 7-32 e 1110-1115; ii) Fragmentos de um poema intitulado "A inauguração do quinto Império 11" - no dito tomo, p. 47 a 52; iii) Parnaso brasileiro ou coleção de poesias dos melhores poetas brasileiros - no mesmo tomo, p. 53 e 
turas do Fanfarrão, D. Pedro II, que em 1845, data da publicação das cartas, contava com a idade de 19 anos e havia sido catapultado ao poder através do chamado "golpe da maioridade".

Segundo Neves (2016, p. 14, grifo nosso), o periódico "pode ser analisado não apenas como um jornal científico e/ou literário, mas também como um meio de veiculação de ideias, conceitos e linguagens políticas que procuravam atingir diversos segmentos da boa sociedade". Não bastassem alguns dados, que serão discutidos adiante, segundo Cairo (1996, p. 47), que se deu ao trabalho de contar e analisar todos os escritos do periódico, Santiago Nunes Ribeiro "funcionou como uma espécie de mentor intelectual de sua geração" e falar dele é falar do periódico Minerva Brasiliense.

Ao contrário de todos os estudos sobre as Cartas chilenas, esta leitura terá como fonte o jornal Minerva Brasiliense, de 1845, pelo fato de ser o momento da primeira aparição histórica das Cartas. Em certo sentido, por um lado, esse fato aponta para a pouca credibilidade que o jornal gozava como fonte no século passado; por outro, não se pode perder de vista que, até o início do Segundo Reinado, o debate político concentrava-se na imprensa e na tribuna do Parlamento. Não obstante, seja pelo curto período em que funcionava o Parlamento, seja pela escassez de espaços de manifestação pública, o "fato é que a imprensa assumia o papel primordial", uma vez que "funcionava todos os dias e atingia um público bem maior do que os clubes e tribuna" (CARvalHo, 2007, p. 17).

Do ponto de vista da história da leitura, pode-se afirmar que cartas não existiam antes de 1845, quando de sua primeira publicação. Não existe um único trabalho sobre a Inconfidência Mineira (vide as referências) que demonstre a existência material desses escritos. Em 184o, Francisco Freire de Carvalho, ao elencar a poesia didática, da qual fazem parte a sátira e a epístola produzidas no Brasil, não faz menção às Cartas chilenas, mas o faz às Geórgicas Brasileiras, composto pelo baiano Prudêncio de Amaral e pelo português José Rodrigues. Todos os estudos seminais sobre o assunto fazem uso da edição de Rubens Borba de Moraes ou de outras consideradas mais "autênticas". ${ }^{2}$ Nos Autos da Devassa da Inconfidência, não há nenhuma referência às Cartas chilenas, propriamente ditas, a não ser em duas passagens, citadas mais adiante, que fazem referências genéricas a papéis. Observa-se primeiro, na fala do Capitão José Lourenço Ferreira, que ali testemunhou que o governador Barbacena "mandaria sair da Capitania o Des. Gonzaga,

seguintes; iv) Relatório do Sr. vereador Gabriel Gomes dos Santos - no mesmo tomo, p. 256-261; e v) A saudade e a despedida, 1837 - no mesmo tomo, p. 376 e seguintes (BlAKE, 1902, p. 194).

2 Entre estes se destacam Maxwell (2010), Furtado (2002), Furtado (1997) e Teixeira (1999); Villalta (1999) utiliza a edição da editora Nova Aguilar, organizada por Domício Proença Filho (1996). Em tese defendida, Anjos (2015) utiliza a versão de Tarquínio de Oliveira (1972). Sobre os manuscritos apógrafos depositados atualmente no Instituto Histórico e Geográfico, de acordo com Lapa (1957, p. 9), "segundo averiguações de Afonso Arinos de M. F, que se socorreu de um perito na matéria, os manuscritos seriam do fim do século XVII, podendo, contudo, datar do século XIX. E uma outra contestação indica que o papel utilizado tem data de 1808 ”. 
e isto por conta ou de um casamento, ou de uns pasquins que se tinham feito públicos" (1976, VII, p. 85) e no depoimento de Frei Rômulo Penaforte (1976, V. IX, p. 177, nota 2), quando afirma que entre os papéis apreendidos aos réus, "acharamse muitas poesias, verdadeiras sátiras contra os europeus e um poema que metia a ridículo todo o governo da Soberana, notícia a mim comunicada por um dos muitos que os sentenciou" (grifos meus). Como demonstra Villalta (1999, p. 340), quando se trata de manuscritos, da mesma forma que os livros, no momento em que foram arrolados nos Autos da devassa tiveram seus títulos citados pela censura. É romântica, portanto, a representação dos manuscritos achados, recuperados e dados à luz no momento em que se construía a identidade nacional e tomava-se a Inconfidência Mineira como "prenúncio do Advento, prefigurando o progresso futuro da Identidade Nacional” (HANSEN, 1997, p. 12).

Não bastasse esse aspecto teleológico levantado por Hansen (1997), pelo menos três outros contribuíram para as leituras românticas e positivistas dessas cartas, os quais elencamos a seguir:

- Certo desprestígio histórico que gozou o período imperial, cujos estudos só foram retomados a partir da década de 1980, com o historiador José Murilo de Carvalho e historiadoras da Universidade do Estado do Rio de Janeiro (UERJ), Tania Bessone e Lúcia Barros.

- O fato de os historiadores da literatura não terem considerado os modos de ler e de escrever nos jornais na primeira metade do século XIX, sobretudo o uso do encobrimento, ou da dissimulation, técnica retórica que consiste em encobrir e dissimular os procedimentos de escrita, manifestados das mais variadas formas. Conforme o que já afirmei em trabalhos anteriores, essa é a primeira das estratégias utilizadas pelos editores dos periódicos dos séculos XVIII, com penetração até o fim do XIX. Partilhada e compreendida pelos leitores, essas astúcias vão além do pseudônimo, do anonimato, das letras invertidas. Elas incluem modificar o gênero do escrito, trocar o autor, recorrer à antiga astúcia de dizer ter encontrado os escritos e até mesmo de encobrir o enredo com ilustrações ou gravuras (BARBOSA, 2015). Esses são elementos constitutivos de alguns periódicos luso-brasileiros e exigem do pesquisador cuidado com as fontes, as citações, as designações de autoria. Por fim, em um tempo em que prevalecia uma outra ordem de discurso na qual não vigorava ainda a "individualização da escrita, a originalidade das obras e a canonização do autor” (CHARTIER, 2012, p. 266), unir escritos de autoria diversa se constituía como modo de escrever próprio aos jornais e ao tempo. No que tange à escrita em jornais e periódicos, basta lembrar os casos célebres de José de Alencar e Machado de Assis e os inúmeros pseudônimos com que assinavam seus escritos nos jornais. Outros havia que nem mesmo assinavam, como é o caso de Manoel Antonio de Almeida, que, em 1852, publicou, no Correio Mercantil, Memórias de um sargento de milícias sem mesmo assiná-lo. Desde o século XIX, as apropriações dessas epístolas 
ignoram outro aspecto fundamental de escrita, que Chartier utiliza para ler Cardenio, bastante comum nos periódicos brasileiros: "trata-se da escrita colaborativa, feita a partir de lugares-comuns partilhados, de fórmulas consagradas, ou ainda de contínuas revisões ou numerosas continuações de obras sempre abertas" (CHARTIER, 2012, p. 267).

Tomemos um exemplo escolhido de um periódico de 1843, o jornal A mulher do Simplício ou a Fluminense exaltada, cujo editor, Francisco Paula Brito, dissimulava sua autoria, assinando a publicação como a Redatora (CALDEIRA, 2012). A coluna do jornal chama-se "Passatempo Dedicado aos Peitos Sensíveis, para Entretenimento". Nessa coluna, ele dá o mote para a criação das glosas. Em duas dessas composições, em dois motes diversos, as glosas citam Marília, como se observa no exemplo a seguir.

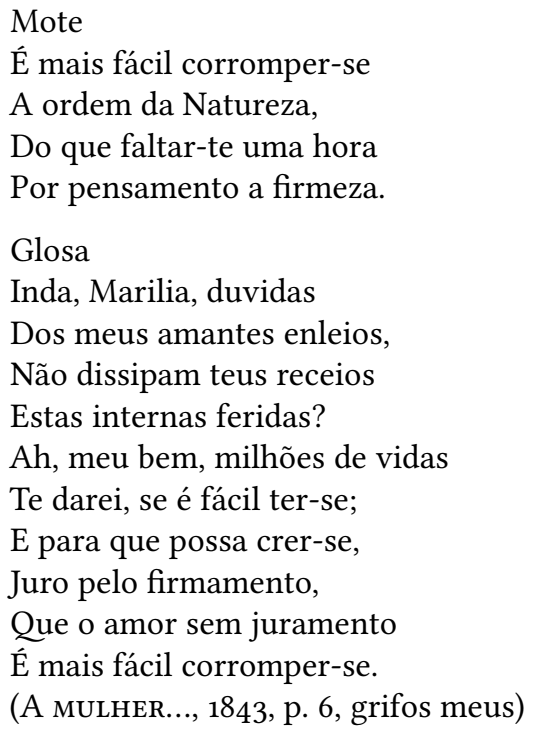

Esse exemplo demonstra, enfim, a necessidade de pensar a dissimulação como economia interna da linguagem, ou seja, como elemento constitutivo de um modo de escrever e de ler de um tempo, nos periódicos luso-brasileiros dos séculos XVIII e XIX. Em outras palavras, a abordagem aqui desenvolvida utiliza a edição da $M i$ nerva Brasiliense, a partir do pressuposto de que o objeto de estudo, alvo da análise, não tem sua escolha por ser a "cópia" mais verdadeira, pois isso pode ser entendido a partir de uma intenção autoral, mas de sua existência histórica (McKENZIE, 2004, p. 19). O que se toma como premissa é o seu testemunho, conforme definido pelo uso histórico.

Por isso, não tratarei das questões relativas às leituras e apropriações das Cartas chilenas, muito bem analisadas por Furtado (1997), que as considera como leituras românticas e positivistas que associaram a publicação à Inconfidência Mineira. Assim, chegar a esta hipótese - de que as Cartas chilenas se constituem como um 
escrito de 1845, provavelmente do chileno Santiago Nunes Ribeiro - exigiu um longo percurso teórico-metodológico que inclui pelo menos dez anos de pesquisa nos e com os periódicos, a partir do pressuposto de que esses formularam uma linguagem própria responsável pela criação de novos gêneros e se utilizaram daquilo que, na retórica, é conhecido como dissimulation (LAUSBERG, 1967), o que, do ponto de vista dos periódicos da época, incluía falsa atribuição de autoria, além de unir escritos de autoria diversa e se constituía como modo de escrever próprio aos jornais e ao tempo

Não bastassem essas questões, tem-se a pouca credibilidade dos periódicos enquanto fonte historiográfica, fonte "pouco confiável". Em recente artigo sobre o periódico Minerva Brasiliense, Tania Bessone (2016, p. 56) questiona se Santiago Nunes Ribeiro é chileno ou peruano. Contudo, do ponto de vista da sátira, as Cartas chilenas não fariam sentido em seu tempo, ou não poderiam ser lidas do ponto de vista satírico, caso não pudesse ser feita a analogia com o seu "autor". Dizendo com Hansen (2004, p. 102):

A sátira não é realista, como se vê, porque tem direção referencial mimetizando casos retóricos, não o referente. Opera, na constituição dos casos, o verossímil como caricatura, monstruosidade. Como artifício que calcula a adequação ao público, é suficientemente inclusiva para ser entendida como paródia por discretos, que conhecem as mesmas referências letradas da persona.

Por último, e não menos importante, tem-se o fato de o gênero "sátira", o componente mais importante dessas epístolas, ter sido compreendido, pelos membros da academia, fora das suas regras pragmáticas, desde que Araripe Júnior escreveu sobre Gregório de Matos. Segundo Hansen (2004, p. 51), "a retórica da maledicência satírica vem sendo entendida, desde que Araripe Jr. assim a entendeu, como psicologia do ressentimento, gesticulação pessimista", ou libelo contra a Coroa e o estabelecido, modo de leitura extensiva a toda e qualquer manifestação satírica. Isso inclui, por exemplo, o fato de a maioria dos historiadores ter esquecido que, na época da Inconfidência, Portugal tinha no seu trono uma Soberana, matéria por excelência da sátira contida nos "papéis apreendidos aos réus", quando "acharamse muitas poesias, verdadeiras sátiras contra os europeus e um poema que metia a ridículo todo o governo da Soberana".

Entendida corretamente, a sátira da Minerva Brasiliense, como aquela do século XVII, "não é oposição aos poderes constituídos", ainda que ataque membros particulares desses poderes". Ademais, deve ser entendida em sua pragmática, o que implica também a decifração de uma escrita regrada, que tem como assunto o tempo presente: "a sátira dramatiza paixões, que estão na natureza, como se escreveu; não é informal, porém, nem psicologicamente expressiva, pois as paixões sofrem codificação retórica, que as regula, distribui e amplifica como natureza discursiva" (HANSEN, 2004, p. 51). 
Passemos à publicação da Minerva Brasiliense. As epístolas foram publicadas no $\mathrm{n}^{\circ}$ 8, incluídas na Biblioteca Brasílica ou Coleção de Obras Originais ou Traduzidas de Autores Célebres, com interesse para a nota explicativa do chileno Santiago Nunes Ribeiro:

Estas cartas merecem a atenção dos poetas e amadores da poesia não só pelo seu merecimento intrínseco, mas por serem atribuídas ao célebre autor da Marília de Dirceu. [...] Um ancião, entusiasta da literatura brasileira, depositário de muitos de seus tesouros, e o que é mais, depositário que não os tem acumulado em seu proveito e sim para o ir dando ao público, um ancião, por estes e outros títulos, benemérito das letras brasileiras, a quem a Minerva deve esta obra (que em atenção ao Sr. Dr. Maia foi-nos permitido imprimir) declara o seguinte acerca dela: "Tenho motivos para certificar que o Dr. Tomás Antonio Gonzaga é o autor das Cartas chilenas. Francisco das Chagas Ribeiro. Tanto basta, em sentir nosso, para que razoavelmente não se possa dizer, sem outras provas, que esta obra é apócrifa” (S.N.R.).

Dessa forma, passa-se a tratar, primeiramente, das Cartas chilenas a partir dos critérios previstos para a sátira, os quais compreendem a sua "função social de reconhecimento", supondo que sua historicidade "de modo algum [é] exterior ou posterior à sua própria história". Por isso, não é conveniente interpretar a sátira, uma vez que "nada oculta", mas "antes relacioná-la com outras práticas e eventos contemporâneos dela" (HANSEN, 2004, p. 406). Segundo, é preciso considerar que, no que concerne à sátira, desde sempre houve uma relação muito estreita entre ela e a política no sentido mais amplo. Para Hodgart (2009, p. 38):

Sátira política precisa de [...] um pouco de sofisticação: sofisticação política (tanto o humorista como o seu público devem compreender alguns dos processos de política) e sofisticação estética (o humorista deve ser capaz de contemplar o cenário político com humor e desprendimento, bem como com paixão, ou ele vai produzir apenas polêmica bruta).

A sátira é, portanto, uma escrita do tempo presente e, como forma mista, "implica apropriação, interpolação, alteração, falsa atribuição etc. Nela o plágio é estrutural" (HANSEN, 2004, p. 44). Por isso, pode-se compreender ao mesmo tempo como arranjo da linguagem da sátira e da escrita jornalística o fato de a "Epístola a Critilo" anteceder as Cartas chilenas. Só para lembrar, quando da publicação dessa, em 1826, o canto do poema Vila Rica, ${ }^{3}$ publicado sob o nome completo de Claudio Manuel da Costa, antecede a "Epístola a Critilo". O efeito é programático e visa sustentar o verossímil da persona satírica.

3 Observe-se a afirmação do redator, segundo a qual este poema já havia sido publicado no jornal O Investigador Portuguez em Inglaterra. 
Em 1845, as Cartas chilenas, publicadas na Biblioteca Brasílica do jornal Minerva Brasiliense, faziam uso da dissimulation, própria à linguagem dos jornais da época, além de outros dois expedientes conhecidíssimos dos leitores. Um desses expedientes diz respeito ao "tema do manuscrito desaparecido e reencontrado, esquecido e depois redescoberto", tão antigo quanto a ficção (CHARTIER, 2012, p. 252). O procedimento adotado por Santiago Nunes Ribeiro de incluir a "Epístola a Critilo" no conjunto das Cartas chilenas é próprio a um tempo e um suporte nos quais observamos a "extrema mobilidade e instabilidade dos textos, constantemente revisados, adaptados, reescritos" (CHARTIER, 2012, p. 264). Um aspecto a ser destacado diz respeito ao fato de que, naquele tempo, após sua publicação, os periódicos eram transformados em livros, o que garante a sua posse e circulação em outra forma. Conforme foi demonstrado, a "Epístola a Critilo" é uma sátira contra D. Pedro I e assim deve ter sido facilmente compreendida no seu tempo. Vale lembrar que essas epístolas foram assinadas por C.M.C. e havia no fornal Científico um trecho da poesia de Claudio Manoel da Costa, Vila Rica. Observa-se, com a atualização de quase vinte anos, que Santiago Nunes Ribeiro utiliza-se da mesma estratégia discursiva para publicar a sua sátira contra Pedro II.

Ao contrário de 1826, quando da publicação da "Epístola a Critilo", em 1845, Tomás Antonio Gonzaga era um autor bastante popular. A título de informação, nesse ano foi publicada uma nova edição do Marília de Dirceu, que até aquela data contava com quinze edições, sendo quatorze delas publicadas em vários lugares do Brasil e duas em Lisboa (Antunes, 2017). Sinônimo do sucesso dessa história de amor é a edição, em 1845, do livro de liras Dirceu de Marília, liras atribuídas a Senhora DMJD de S (Natural de Vila Rica), organizada por Joaquim Norberto de Sousa e Silva, coincidentemente publicado em 1845, em cujo prefácio anuncia:

Não serei eu que afirmarei ou negarei a autenticidade da presente coleção de Liras extraídas de uma cópia que se me afirma ter sido tirada de manuscritos autênticos, cuja ortografia não pude conservar que não me permitiu a brevidade do tempo que tinha a dispor. Apócrifas ou originais, completam elas a história dos amores e saudades desses amantes desgraçados que a poesia começou por celebrar e que os homens acabaram por imortalizar; os nomes de Marília e Dirceu se tornaram populares em todo o Brasil, e hoje retumbam pela Europa e América, e um dia se unirão aos de Hero e Leandro, Safo e Fauno, Heloísa e Abelardo, Inês e Pedro, Laura e Petrarca, e então serão populares em todo o mundo (SILVA, 1845, p. 3)

Por fim, considera-se também que encontrar manuscritos no começo do século XIX se transformou em um topos que favorecia o caráter de veracidade à prosa de ficção. Os manuscritos anonimamente encontrados por ou entregues àquele que o dava a público tinham, portanto, a função da captatio benevolentiae (LAUSBERG, 1967) tão conhecida da retórica. Aos historiadores da literatura do século XX passou despercebida a alegoria como linguagem usual daquele tempo. Segundo Lopes Gama, "a alegoria é muitas vezes um meio astucioso de dar lições a homens, 
a quem a cegueira das paixões ou orgulho do poder faria cegos ou rebeldes à verdade. A alegoria torna-se necessariamente o tropo usual do escravo que quer dar a entender suas queixas legítimas sem o risco de ofender seu senhor (GAMA, 1846, p. 146). Razão pela qual, justifica-se o estilo empregado - a sátira, uma forma de linguagem alegórica - para consertar os vícios do governo, a partir de uma das maneiras mais eficazes de escrever política de forma "indireta, útil e circunspecta". Como afirma o editor:

Dois são os meios porque nos instruímos; um quando vemos ações gloriosas, que nos despertam os desejos da imitação, outro quando vemos ações indignas, que nos excitam o seu aborrecimento. Ambos estes meios são eficazes: esta a razão porque os teatros instituídos para a instrução dos cidadãos, umas vezes nos representam a um herói cheio de virtudes, e outras vezes nos representam a um monstro coberto de horrorosos vícios (Minerva ..., 1845a, p. 9).

Usadíssima nos periódicos, também teve suas glórias em várias cerimônias do Império, como a Coroação do jovem Pedro II. Segundo Schwartz (2004, p. 75), um dos aspectos do espetáculo de sagração do jovem Imperador foi o uso de "símbolos e alegorias criados com o propósito de denotar os anseios da elite política do país e o perfil que o jovem Pedro deveria representar para a nação e, paralelamente, para os súbditos do Império: a imagem do novo reino". O que nos remete ao fato de que os súditos do jovem imperador eram capazes de entender os meandros significativos dos termos alegóricos, também nos textos escritos.

Publicada em um escrito satírico, a nota de Santiago Nunes Ribeiro anteriormente citada deve ser compreendida segundo os protocolos de leitura próprios à sátira, e como tal o foi pela comunidade de leitores que a liam na perspectiva do presente de sua publicação. Assim, a estratégia de juntar as duas epístolas garante uma leitura mais verossímil, unindo o pai ao filho, se não pela moral, pelo menos pela herança satírica. É preciso não esquecer que a lembrança de D. Pedro I e sua biografia escandalosa ainda eram assunto recorrente na época e a comparação entre pai e filho era inevitável. ${ }^{4}$ Ademais, como afirma Carvalho (2007, p. 360), naquele tempo:

As obras destinadas ao público em geral, como livros ou artigos de jornal, constituíam muitas vezes verdadeiras declarações de princípios políticos

\footnotetext{
4 Em uma carta de um leitor, publicada no dia 22 de abril de 1843, no Diário do Rio de faneiro, lê-se o seguinte: "Carta ao Redator de 'Um fiel respeitador das virtudes do Sr. D. Pedro 10'. Se ouvi com prazer a apostrofe que a S. M. o Imperador dirigiu o Sr. Cônego Brito no sermão de sexta-feira santa na Capela Imperial, muito admirei que S.S. trazendo à lembrança do monarca os modelos de piedade de seu augusto avô, e da virtuosa imperatriz Leopoldina, não fizesse também menção de seu augusto e generoso pai! [...] As fraquezas do monarca, como homem, não devem nunca escurecer suas virtudes: e qual o homem que está isento de fraquezas?” (DiÁrIO..., 1843, p. 2).
} 
ou eram parte da estratégia da luta partidária. Como tais, podiam não representar com exatidão a posição dos autores, podiam conter, como cremos de que fato continham, aspectos retóricos que não resistiriam ao enfrentamento de problemas concretos de decisão política.

Em linhas gerais, pode-se afirmar que os assuntos do Império assim como os das Cartas chilenas são muitos e mantêm essa dinâmica, tal qual as atas do Conselho do Império, consultadas por Carvalho. Existem nas epístolas uma série de fatos relacionados, ações administrativas do Imperador, a que uma pesquisa mais cuidadosa junto aos documentos oficiais poderá dar sentido. Esse é o caso específico da Carta $7^{\mathrm{a}}$, "Em que se trata da venda dos despachos e contratos". Nesse caso, os decretos, atas e outros documentos do Império poderão ser consultados para efeito de "estabelecer uma cartografia móvel de eventos e posições" (HANSEN, 2004, p. 107). Como já observou Schwartz (2004, p. 43), "o Império brasileiro produziu muitas imagens, que parecem constituir parte fundamental de sua efetivação. Em diferentes momentos da vida de D. Pedro II, a ampla iconografia encontrada é quase um trunfo, e as imagens parecem dirigir a reflexão". Por essa razão, elegi, principalmente, as imagens como o registro de intervenções que se perspectivam com a murmuração das Cartas chilenas, aliadas aos temas mais importantes naquele momento, são eles: a pouca idade de D. Pedro II e sua inadequação ao cargo, os gastos com o seu casamento, a Revolução Farroupilha e a construção da Casa, que levou anos e consumiu muito dinheiro.

Conforme já mencionei anteriormente, é interessante que todos os que leram as Cartas chilenas não tenham observado que elas se referem a um "monarca", a um "reino" e a "nosso Augusto", termos amplamente repetidos, não compatíveis, portanto, com o tempo da Inconfidência Mineira, quando reinava a soberana, D. Maria I. Outra marca temporal deixada de lado por historiadores diz respeito à passagem do Cometa Caudato, uma marca de que as epístolas são de 1845 . Segundo Lima (1845, p. 398), a passagem do Cometa Caudato ocorreu em 28 de fevereiro de 1843, "porém não foi mais visto de dia, até que no dia 5 de março, em que subiu a Divisão naval, que foi buscar a futura Imperatriz do Brasil, tornou a aparecer logo à noite com sua majestosa cauda". Esse cometa também é descrito na "Ode à Paz na Província do Rio Grande do Sul, Tributo da mais cordial amizade, do mais sincero respeito e gratidão ao Exm. Sr. marechal conde de Caxias”, escrita por D. J. Gonçalves de Magalhães e publicada no $\mathrm{n}^{\circ} 12$ da Minerva Brasiliense, de 15 de maio de 1845 , sobre a qual trataremos adiante.

Observa-se na leitura das Cartas chilenas, atribuídas a Tomás Antonio Gonzaga, um modo de lidar com as fontes, que já estabelece uma pragmática, colada ao imaginário romântico, que transformou em mito esse período (FURTADO, 2002), de tal forma que não se lê o que parece óbvio: todas as epístolas dizem respeito a um monarca, a um reino e é a sua conduta, e não a monarquia, que é satirizada. Entre outros momentos, a Carta 1a, "Em que se contam vários sucessos da entrada 
que fez em Chile Fanfarrão Minézio", satiriza a coroação de D. Pedro II, como se mostra nos versos a seguir:

Chega-se o dia da funesta posse;

Mal os grandes se ajuntam, desce a escada,

E sem mover cabeça vai meter-se

Debaixo do lustroso e rico palio.

Caminham todos juntos para o templo:

Um salmo se repete em doce choro,

Aquele assiste desta sorte inchado.

Entesa mais que nunca o seu pescoço,

Em ar de minuete os pés conserta,

E arqueia o braço esquerdo sobre a ilharga. (Minerva..., 1845a, p. 22, grifo nosso)

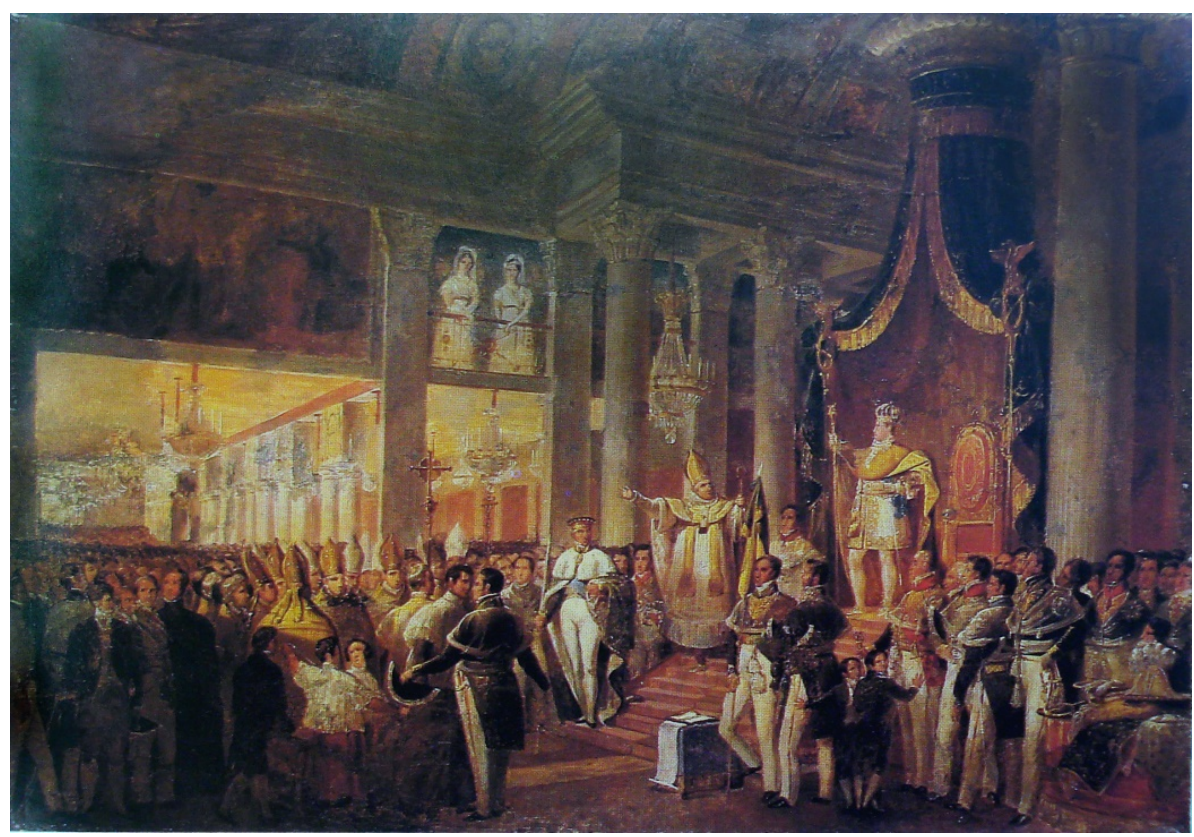

Fig. 1 - Ato solene da coroação do imperador: em destaque, na varanda, as duas princesas imperiais, e ao centro, de perfil, a figura corpulenta do mordomo-mor Paulo Barbosa.

Estudo de Manuel de Araújo Porto Alegre, c. 1843.

Fonte: Schwartz (2004).

A sátira ao Imperador inicia com o uso da tópica da constituição física. Não é demais lembrar que, em 1845, D. Pedro II tinha 19 anos e havia sido alçado à condição de imperador com 14 anos, a partir do que se convencionou chamar de golpe da maioridade. Por isso, o "moderno chefe", a despeito da "estatura um tanto esbelta”, imita Sancho Pança, sujeito pequeno, que se apequena ainda mais ao concordar com as fantasias de D. Quixote: 
Escuta a história de um moderno chefe,

Que acaba de reger a nossa Chile,

Ilustre imitador de Sancho Pança.

E quem dissera, amigo, que podia

Gerar segundo Sancho a nossa Espanha.

$[\ldots]$

Tem pesado semblante, a cor é baça;

O corpo de estatura um tanto esbelta;

Feições compridas, e olhadura feia;

Tem grossas sobrancelhas, testa curta,

Nariz direito, e grande; fala pouco,

Sem ser velho já tem cabelo ruço;

E cobre este defeito, a fria calva

A força de polvilho que lhe deita.

Nariz direito, e grande; fala pouco,

Em rouco baixo som de mau falsete;

[...]

O rir-se um cônsul moço, que fizeras

Se em Chile agora, entrasses, e se visses

Ser o rei dos peraltas quem governa?

[...]

Deviam, Doroteu morrer os povos

Apenas os maiores imitaram

Os rostos, e os costumes das mulheres

Seguindo as modas e rapando as barbas.

(Minerva..., 1845a, p. 17-18, grifo nosso)

Lembro que essa Carta $1^{\text {a }}$ faz referência ao tempo em que o Fanfarrão entrou no Chile, um peralta, imberbe, fato muito ressaltado no tempo da sua coroação, signo de sua imaturidade política. É possível identificar nessa descrição algumas características do jovem monarca, motivo de riso e apreensão, entre as quais se destacam "o semblante sério e compenetrado pouco combinava com a fisionomia jovem, e a voz fina". Com efeito, "as barbas do imperador" foram motivo de constante debate e de grande apreensão desde os primeiros anos de sua adolescência (SchWARTZ, 2004, p. 96). Na sátira, a constituição física e a feiura humana estão divididas em duas partes, do ânimo e do corpo: "feiura do ânimo derivada da maldade ou da estupidez; feiura do corpo dolorosa e nociva ou não dolorosa e inócua" (HANSEN, 2004, p. 395).

Ressalta-se, nesse caso, que a feiura do monarca é inócua, mas como seu ânimo é comparado ao de Sancho Pança, tem-se que a feiura se relaciona à estupidez. A seguir temos duas representações de D. Pedro II. A primeira (Figura 2), uma gravura, provavelmente confeccionada fora das instituições oficiais, representa melhor este janota, com jeitos adamados, como informa versos da carta, cujos cabelos foram tingidos de preto. A segunda (Figura 3), a cópia oficial de um jovem feio e imberbe, cujos cabelos louros pareciam ser um problema em uma nação for- 
mada majoritariamente por negros e mestiços. Esses traços salientam a expressão de José Murilo de Carvalho de que ele era "um Habsburgo perdido nos trópicos".

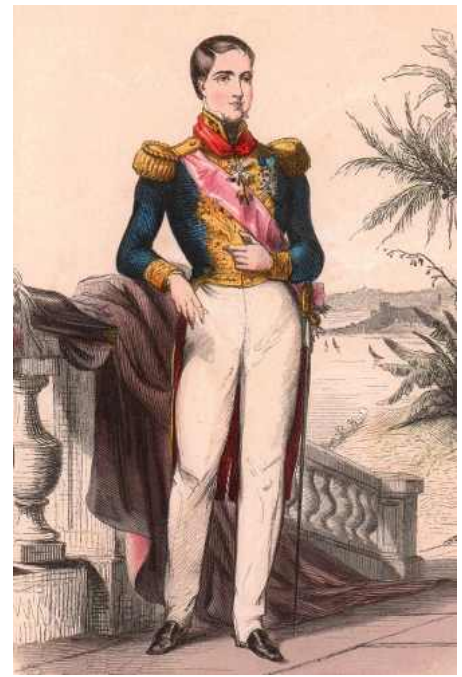

Fig. 2 - D. Pedro II - Gravura de 1845 (Anônima).

Fonte: Arquivo Nacional do Brasil.

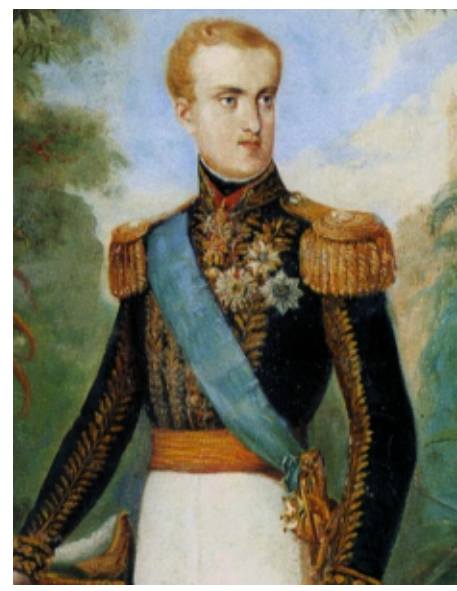

Fig. 3 - D. Pedro II, em 1846, por Johann Moritz Rugendas. Fonte: https://rainhastragicas.com.

No Dicionário da Língua Portuguesa (1831), de Antonio de Morais, a palavra ainda é gravada como paralta, ${ }^{5}$ mas admite peralta: seja qual for a grafia, seu significado remete para jovem galante, mancebo presumido, petimetre, jovem ada-

5 Na edição de 1824, não constam nenhum dos termos, mas era corrente o seu uso nos jornais e folhetins jocosos do século XVIII de Portugal. Encontra-se na edição de 1831. Petimetre. s.m. o mancebo que com demasia anda atilado, enfeitado, e é dos primeiros seguidores das modas: $t$. moderno usual (do francês petmaitre). V. Glossário por D. Fr. Francisco de S. Luiz, p. 105. Podemos 
mado, que afeta mil jeitos, bem como pedante. Para o leitor de 1845, a amplificação das descrições - ou seja Sancho, peralta e imberbe - visa à recepção, adequandose a ela: "a mesma exageração, muito sumária, é apreendida imediatamente como tal, não exigindo o juízo ou a análise demorada e exaustiva" (HANSEN, 2004, p. 395). E essa caracterização estará presente também na Carta $2^{\mathrm{a}}$ "Em que se mostra a piedade que Fanfarrão fingiu no princípio do seu governo para chamar a si todos os negócios”. Não podemos deixar de chamar a atenção para o perfil caricato da sátira, cujas descrições são retóricas, não realistas:

\author{
Esperava acaso um bom governo \\ Do nosso Fanfarrão? Tu não o viste \\ Em trajes de casquilho nessa corte? \\ E pode, meu amigo, de um peralta \\ Formar-se de repente um homem sério (Minerva..., 1845a, grifo nosso)
}

São estes mecanismos próprios à linguagem da sátira que possibilitam identificar Robério, que se põe atrás do chefe, como o mordomo Paulo Barbosa da Silva, e Matusio, outro conselheiro do jovem Pedro II, Aureliano Coutinho que, junto com D. Mariana de Werna, constituíam o poder palaciano, a "facção áulica". Segundo Schwartz (2004, p. 80), "a influência desses três personagens na vida de d. Pedro é de tal monta que mal se encontram descrições que falem do jovem príncipe sem a remissão a um desses nomes":

Que entre os criados tem respeito de aio;

Estatura pequena, largo o rosto,

Delgadas pernas, e pançudo ventre

Sobejo de ombros, de pescoço falto,

Tem de pisorga as cores, e conserva

As bufantes bochechas sempre inchadas.

Bem que já velho seja inda presume

De ser aos olhos das madamas grato;

E o demo lhe encaixou que tinha pernas

Capazes de montar no bom ginete,

Que rincha no Parnaso. Pobre tonto! (Minerva..., 1845a, p. 18, grifo nosso)

Nesse caso, a feiura do corpo é nociva, aliada à feiura do ânimo, representada pelas cores da pisorga, ou bebedeira. $\mathrm{O}$ termo pisorga não se encontra registrado em dicionários da época. Fui encontrá-lo na Coleção de provérbios, adágios, rifões anexins, sentenças morais e idiotismos da língua portuguesa, editada no Rio de Janeiro em 1848, pelos irmãos Laemmert. Outra tópica nessa descrição de Paulo Barbosa da Silva é a da idade, representada por um velho ridículo, que não sabe o seu lugar, ação que revela imprudência aos olhos da persona satírica. Como se sabe, a sátira

dizer peralta, peralvilho, casquilho, mancebo presumido, garrido, rapaz adamado, que afeta mil modos e jeitos no falar e trajar, talvez pedante, etc. 
não está contra a moral (HANSEN, 2004) e o perfil do mordomo se mostra incompatível com o cargo que exerce, inclusive sendo responsável pelas finanças públicas.

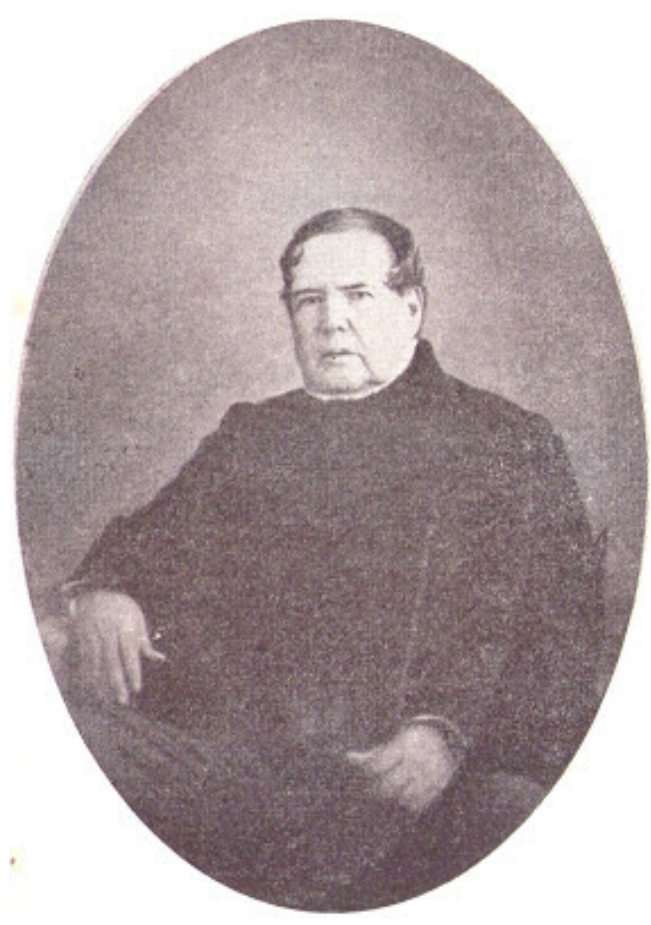

Fig. 4 - Mordomo de D. Pedro II, Paulo Barbosa da Silva. Fonte: http://ahistoriadepetropolis.blogspot.com.br.

Outro aspecto que deve ser considerado, quando da leitura da Carta ${ }^{\mathrm{a}}$, para uma visão caricatural de um monarca fraco, portanto, pouco condizente com o cargo que ocupa, diz respeito ao acordo estabelecido pelo Barão de Caxias com o chefe dos Farrapos, Bento Gonçalves. É importante ressaltar que a Revolução Farroupilha não assume na historiografia sobre o Segundo Reinado a importância e dimensão que tem na historiografia gaúcha, amplamente explorada, o status, segundo Sandra Pesavento (2003, p. 70), "de epopeia". Além disso, continua a historiadora, essa mesma historiografia conseguiu transformar a luta de um grupo hegemônico, sacralizando-a, como "passado dignificante", herança não só dessa elite, mas de todo o povo rio-grandense, porque mantém viva "a presença do episódio, da glorificação de seus heróis e da exaltação das virtudes” (Pesavento, 2003, p. 70) como sendo de todo o Rio Grande do Sul.

Envia, Doroteu, vizinho chefe Ao nosso grande chefe outro soldado Por vários crimes convencido, e preso. Lançasse o tal soldado de joelhos. Aos pés do seu herói suspira e treme; Não nega que ferira e que matara: 
Mas pede que lhe valha a mão piedosa

Que tudo pôde, que ele aperta e beija.

Pergunta-lhe o bom chefe: se os seus crimes

Divulgados estão, e o camarada

Com semblante já leve lhe responde:

Que suas graves culpas foram feitas

Em sítios mui distantes desta praça.

Então, então o chefe compassivo

Manda tirar o ferro dos seus braços.

Dá-lhe um salvo-conduto, com que possa,

Contanto que na terra se não saiba,

Fazer impunemente insultos novos. (MINERVA..., 1845a, p. 29, grifo nosso)

O que parece incomodar a persona satírica e envergonhar o "reino da Espanha" é o pacto estabelecido entre o Império e os farrapos, no qual foi-lhes oferecida uma "paz honrosa". Segundo Sandra Pesavento (2003, p. 64), "os farrapos não sofreram uma derrota final nos campos de batalha, apesar de se encontrarem já bastante desgastados". Ademais foram oferecidas vantagens aos revoltosos e atendidas antigas reivindicações, entre as quais o direito de os estanceiros gaúchos escolherem o presidente de província. Somem-se a essas, o fato de que:

[...] as dívidas da República Rio-grandense seriam pagas pelo governo central; os generais farrapos poderiam, se o quisessem, passar para o exército brasileiro com os mesmos postos que ocupavam nas forças rebeldes; o governo central garantia o direito de propriedade e a segurança individual de todos os revolucionários; os prisioneiros de guerra seriam soltos, e aqueles que estivem fora da província poderiam retornar sem receito; seria elevada em $25 \%$ a taxa alfandegária sobre a entrada do charque platino no mercado brasileiro; o governo reconheceria a liberdade dos escravos que haviam servido na revolução como soldados (Pesavento, 2003, p. 64-65).

As negociações tiveram início em $1844 \mathrm{e}$, em $1^{\circ}$ de março de 1845 , foi assinado o Tratado do Poncho Verde, pelo qual todos os rebeldes foram perdoados e o território do Rio Grande do Sul se reintegrou ao império (Luvizotto, 2009). Como já se observou, a Carta $2^{\text {a }}$ se denomina "Em que se mostra a piedade que Fanfarrão fingiu no princípio do seu governo para chamar a si todos os negócios”.

Conforme já mencionei anteriormente, o Rio Grande e a guerra dos Farrapos frequentaram as páginas do Minerva Brasiliense, no n. 12, de 15 de maio de 1845. A primeira refere-se, segundo nota de rodapé, à primeira vez em que o cometa foi visto, dia $1^{\circ}$ de março de 1843 , dia em que Caxias "levantou acampamento e fez sua primeira marcha em direção ao ocidente onde estava o inimigo" (Minerva..., 1845b, p. 183). O segundo, também informa outra nota, alude ao cometa visto no princípio do ano de 1845 [sic] quando se tratava de paz. Em toda a Ode não se observa uma menção ao Imperador, mas ao Império. O "eu-lírico", contudo, justifica 
o recuo do castigo pelo laço fraterno que os une à pátria, o que reforça a afirmativa de que o perdão foi um assunto do momento e que não foi recebido de forma pacífica por todos do reino.

Bravos do império! (diz) Eia, voemos

Contra filhos que a pátria renegaram;

(Ingratos!) castiguemos

O ímpio crime de que eles se mancharam;

Mas no furor da pugna nos lembremos

Que são nossos irmãos, e os amamos;

Se a morte nos juraram,

Nós, vencendo-os, à pátria inda os chamamos (Minerva..., 1845b, p. 183)

O outro tópico com mais visibilidade nessa carta diz respeito à construção da cadeia, tema a que se dedicam a Carta $3^{\text {a }}$ "Em que se contam a injustiça e violências que Fanfarrão executou por causa de uma cadeia, a que deu princípio" e a Carta $4^{\text {a }}$ "Em que se continua a mesma história".

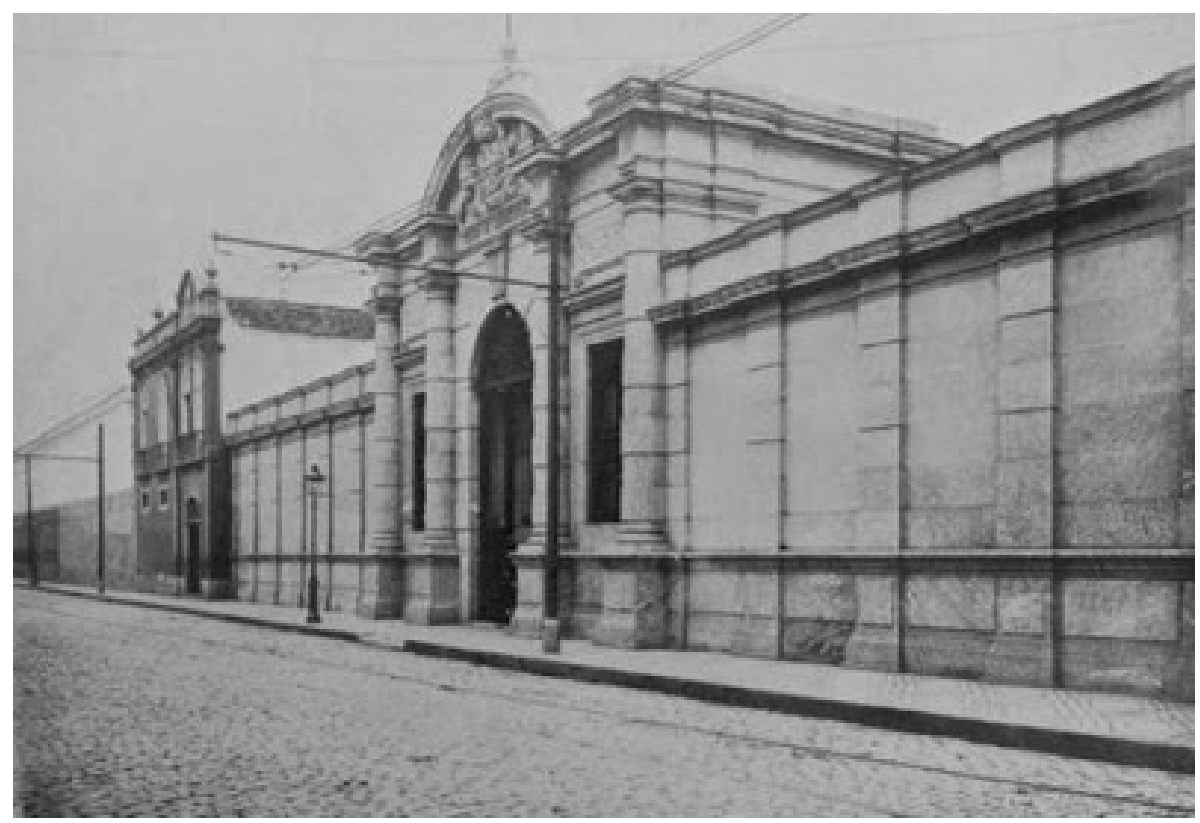

Fig. 5 - Arcos da entrada da Casa de Correção, inaugurada em 1850. Fonte: http://riodejaneiroqueeuamo.blogspot.com.br.

A Casa de Correção do Rio de Janeiro, também chamada Casa de Correção da Corte, foi criada em 6 de julho de 1850 pelo Decreto $n^{\circ} 678$, após 16 anos de construção. "No final de 1831 uma comissão formada por membros da Sociedade Defensora da Liberdade e Independência Nacional elaborou o projeto arquitetônico da Casa de Correção da Corte, inspirado no modelo proposto por Jeremy Benthan", conhecido como Panóptico, cujo objetivo principal era o de manter sob constante 
vigilância os indivíduos - presos, estudantes ou religiosos (ArAújo, 2007, p. 6). Exagerando a caricatura do chefe, a construção da cadeia assume a desproporção do seu espírito fraco que expressa "falsa compaixão" (MinervA..., 1845a, p. 37).

Pretende, Doroteu, o nosso chefe

Erguer uma cadeia majestosa,

Que possa escurecer a velha fama

Da torre de Babel, e mais dos grandes

Custosos edifícios que fizeram

Para sepulcros seus os reis do Egito.

[...] Ora pois, doce amigo, vou pintar-te

Ao menos o formoso frontispício

Verás, se pede máquina tamanha

Humilde povoado, onde os grandes

Moram em casas de madeira a pique.

Em cima da espaçosa escadaria

Se fôrma do edifício a nobre entrada

Por dois soberbos arcos dividida:

Por fora destes arcos se levantam

Três jônicas colunas, que se firmam

Sobre quadradas base, e se adornam

De lindos capiteis, aonde assenta

Uma formosa, regular varanda.

Seus balaústres são de lizas pedras,

Que brandos ferros cortam sem trabalho.

Debaixo da cornija, ou projetura

Estão as armas deste reino abertas

No liso centro da vistosa tarja. (MINERVA..., 1845a, p. 37-38)

A construção dessa casa, iniciada em 1836, constituiu-se como um "ambicioso" e caro projeto do Estado Monárquico, cujo orçamento inicial foi de cerca de 3 mil e 200 contos de réis, considerando-se as turbulências político-econômica do período Regencial (REIS, 2005).

Como observa Reis (2005), isto significava $1 / 5$ da receita anual do Império que era de 16 mil contos de réis, o que também correspondia a três vezes as dotações anuais do Ministério da Justiça. À persona satírica pareciam desproporcionais os gastos empreendidos pelo tesouro para abrigar negros, em um reino onde os chefes residiam em casas sem janelas. Por isso, indignada, informa a Doroteu a que se destina tão vistoso edifício: "E sabes para quem?/ Também não sabes/ Pois eu também o digo / Para uns negros,/ Que vivem (quando muito) em vis cabanas / Fugidos dos senhores lá nos matos" (Minerva..., 1845a, p. 38, grifo nosso). Para fazer frente aos custos da obra, os "titulares da pasta da Justiça lançaram mão com frequência do recurso das subscrições públicas, conclamando a população, sobretudo os membros das elites, a colaborarem com o empreendimento que só lhes traria benefício" (ReIs, 2005, p. 3). 
Pode-se afirmar que os jornais, assim como atas e decretos, e a vasta iconografia do Império se constituíam como a murmuração do tempo, formando os discursos formais e informais do local, que foram transformados comicamente nas Cartas chilenas. As Cartas $5^{\text {a e }} 6^{\text {a }}$ referem-se ao casamento de D. Pedro II: a Carta $5^{\text {a }}$ "Em que se contam as desordens feitas nas festas que se celebraram nos desposórios do nosso sereníssimo infante com a sereníssima infanta de Portugal"; e a Carta $6^{\text {a }}$ "Em que se conta os restos dos festejos". Segundo Schwartz (2004, p. 130), só nos preparativos do casamento "gastaram-se 3:555\$0oo com o retrato do imperador, o presente para a futura imperatriz (um anel de rubi e ametistas, circundado por brilhantes) e barras de ouro". Essa é a primeira queixa da persona satírica: os custos da cerimônia.

Chegou, à nossa Chile a doce nova

De que real infante recebera

Bem digna do seu leito casta esposa,

Reveste-se o paxá de gênio alegre,

E para bem fartar os seus desejos,

Quer que as despesas do senado e povo

Arda em grandes festins a terra toda.

Escreve-se ao senado extensa carta

Em ar de majestade, em frase moura,

E nela se lhe ordena que prepare

Ao gosto das Espanhas, bravos touros. (Minerva..., 1845a, p. $5^{8}$ grifo nosso)

Esse assunto aparece várias vezes ao longo da Carta $6^{\mathrm{a}} \mathrm{e}$ ajuda a reforçar a caricatura do Fanfarrão, traçada pela persona ao longo das outras epístolas:

E enquanto entende que o senado zela

Mais as leis que o seu gosto, não descansa.

Aos tristes senadores não responde,

Mas manda-lhes dizer que a não fazerem

Os pomposos festejos, se preparem

Para serem os guardas dos forçados,

Trocando as varas em chicote e relho.

[...]

Huns dizem, que das rendas do senado,

Tiradas as despesas pouco sobra;

Os outros acrescentam, que se devem

Parcelas numerosas impagáveis,

As consternadas amas dos expostos.

Uns ralham, outros ralham: mas que importa

Todos arbítrios dão, nenhum acerta.

Então o grande Alberga $a^{6}$ que preside,

\footnotetext{
6 O termo "alberga" não se encontra grafado no Dicionário de Antonio de Morais Silva. Registra apenas Albergar como v. at. Dar hospício, aposentar-se; albergaria, s. f. hospício; estalagem, casa de aposentadoria.
} 
Vendo esta confusão na mesa bate,

E levantando a voz pausada, e forte,

A importante questão assim decide

Ha dinheiro, senhores, há dinheiro: (Minerva..., 1845a, p. 6o-61, grifo do autor)

O certo é que a cerimônia se realizou com as pompas previstas, conforme Schwartz (2004, p. 130),

Às onze horas o casal real sairia de bordo e iria em carruagem real rumo a um te-déum e ao ritual do beija-mão. Depois seguiriam um minucioso roteiro que incluía folguedos, jantar de gala no Paço de São Cristóvão e bailes nas paróquias em que os escravos estavam autorizados a exibir suas danças em homenagem a S. M. Imperial.

Chamo a atenção para a presença dos escravos e dos folguedos nessa cerimônia, cujo registro iconográfico cuida de apagar esta parte da festa. Ademais, o quadro pintado por Alessandro Cicarelli, em 1846, reafirma a murmuração do fato três anos após o ocorrido. Hierarquizando os vícios desse reino, a persona divide a cerimônia em duas cartas A primeira destinada a descrever os rituais dos quais o Fanfarrão e sua entourage participam, da qual são personagens ele e Robério.

Adaptando a abordagem que Hansen estabelece em relação à sátira de Gregório de Matos e aos documentos da Câmara, o que se busca aqui é demonstrar a relação das Cartas com a iconografia e o discurso dos periódicos, reafirmando, dessa forma, que "a sátira não os ilustra ou vice-versa. A correlação formula um registro de intervenções de várias formas - ordens, censuras, consenso, exclusão, inclusão - e de temas" (Hansen, 2004, p. 108, grifos do autor). No caso do Segundo Reinado, os temas são as finanças, o casamento, o beija-mão, o te-déum, os folguedos, a presença dos escravos e da nobreza, numa pragmática generalizada na qual os temas e a posição dos agentes se perspectivam.

A Carta $6^{\mathrm{a}}$ "Em que conta os restos dos festejos" retrata a corte do Fanfarrão, formada por antigos almocreves, alfaiates e tendeiros (p. 68). É possível observar que a persona combina com o senso comum de que trabalhos manuais não são compatíveis com a posição da "nobreza" e a questionável forma de se tornar nobre no Brasil, totalmente centralizada na figura do imperador (SCHWARTZ, 2004).

Em ar civil e grato: só o chefe

O corpo da cadeira não levanta

Nem abaixa a cabeça; qual o dono

Dos míseros escravos, quando juntos

A benção vão pedir-lhe, porque sejam

Ajudados de Deus no seu trabalho.

$[\ldots]$ 


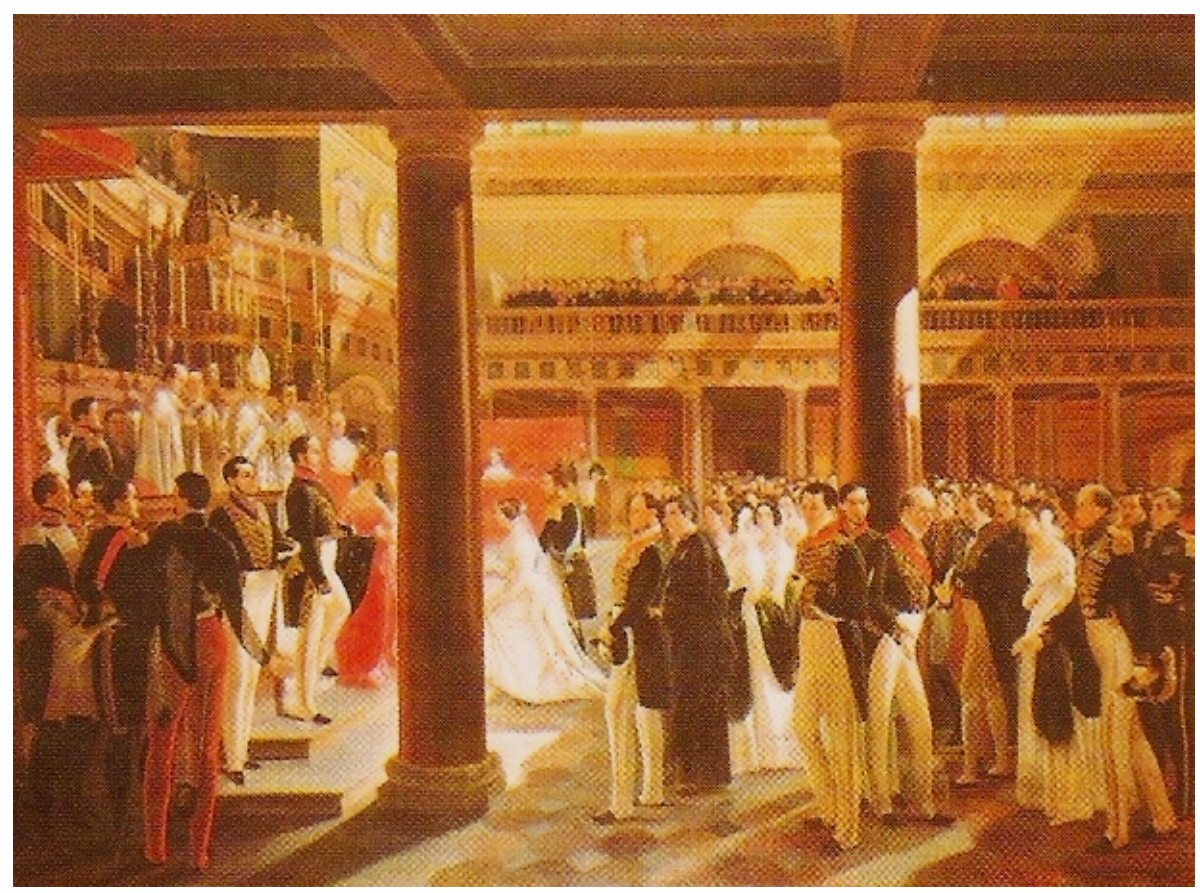

Fig. 6 - Casamento por procuração da imperatriz Dona Tereza Cristina, por Alessandro Cicarelli, 1846. A cerimônia foi realizada na Capela Real Palatina, em Nápoles, a 30 de maio de 1843.

Fonte: https://docs.ufpr.br.

Aqui lascivo amante sem rebuço A torpe concubina oferta o braço; Ali mancebo ousado assiste, e fala À simples filha, que seus pais recatam. A ligeira mulata em trajes de homem Dança o quente lundum, e o vil batuque: Aos cantos do passeio inda se fazem Ações mais feias, que a modéstia oculta. Meu caro, Doroteu, meu doce amigo, Se queres que este sitio te compare

Como sério poeta, aqui tens Chipre

Nos dias em que os. povos tributavam

À deusa tutelar alegres cultos. (MINERvA..., 1845a, p. 71-73)

$\mathrm{Na}$ Carta $6^{\mathrm{a}}$ são inúmeras as alusões a tipos e comportamentos frequentes que apontam para "discursos locais". Contudo, na sátira, a descrição de cenas da "realidade" ou de costumes não se faz numa perspectiva de ser uma crônica, "expressão do vivido, do contexto, pretexto ou subtexto, tampouco reflexo de práticas”. Segundo Hansen (2004, p. 109), "o que se encenam são discursos do lugar para tipificação dos viciosos”. Por exemplo, na figuração abaixo, endossada por outros 
termos como Sodoma e Gomorra (p. 74) vitupera-se não apenas o Fanfarrão, mas todo o seu reino:

\author{
Ninguém antigamente se sentava \\ Senão direito, e grave nas cadeiras, \\ Agora as mesmas damas atravessam \\ As pernas sobre as pernas. Noutro tempo \\ Ninguém se retirava dos amigos, \\ Sem que dissesse, - adeus - agora é moda \\ Sairmos dos congressos em segredo \\ Pois corre, Doroteu, a paridade, \\ Que os costumes se mudam com os tempos. (Minerva..., 1845a, p. 64)
}

Concluindo, pode-se afirmar que esta leitura não é a mais correta nem a mais completa das Cartas chilenas, de Santiago Nunes Ribeiro, publicadas no jornal Minerva Brasiliense, mas é a que tenta se aproximar desses escritos, de uma forma mais verossímil, considerando algumas especificidades fundamentais no processo de escrita nos periódicos luso-brasileiros do século XIX, quais sejam: a existência histórica dessas cartas, noticiadas apenas em 1845; o modo de escrever nos periódicos, caracterizado pela dissimulação, que incluía anonimato, pseudônimo e outras estratégias tais como a do manuscrito encontrado e até mesmo a da falsa atribuição de autoria, lembrando outra concepção de autor; por fim, as estratégias da sátira, como escrita regrada que fere para curar. Esta leitura não está completa. $\mathrm{O}$ uso de documentos oficiais do Império e outras fontes poderão ampliá-la e lançar luz sobre este monumento brasileiro chamado Cartas chilenas.

\title{
Referências
}

A mulher do Simplício ou a fluminense exaltada. Rio de Janeiro, 23 dez. 1843. n. 76 .

Antunes, Cristina. As edições de "Marilia de Dirceo", de Tomás Antônio Gonzaga. 2017. Disponível em: https://www.bbm.usp.br/node/72\#nota1. Acesso em: $26 \mathrm{fev}$. 2018.

Araújo, Carlos Eduardo Moreira de. Corrigindo os desviantes: a construção do sistema prisional no Brasil - Uma perspectiva comparativa. Rio de Janeiro e Rio Grande do Sul, século XIX. Atas do $3^{\circ}$ Encontro Escravidão e liberdade no Brasil meridional, 2007. p. 6-13. Disponível em: http://www.escravidaoeliberdade.com. $\mathrm{br} /$ site/images/Textos3/corrigindo\%20os\%2odesviantes.pdf. Acesso em: $26 \mathrm{fev}$. 2018.

Autos de Devassa da Inconfidência Mineira. 2. ed. Brasília: Câmara dos Deputados; Belo Horizonte: Imprensa Oficial, 1976. 
BARBosA, Socorro de Fátima P. A introdução às Cartas chilenas ou Epístola a Critilo e a murmuração da corte no primeiro reinado. Veredas, Santiago de Compostela, n. 19, p. 201-236, 2013.

Barbosa, Socorro de Fátima P. Romance e dissimulação na escrita dos periódicos luso-brasileiros do século XIX: Adelaide de Sargans, Asarce e Ismênia e Cartas de uma peruviana. Miscelânea, Assis, v. 18, p. 59-79, jul./dez. 2015.

Blake, Augusto Vitorino Sacramento. Dicionário biobibliográfico brasileiro. Rio de Janeiro: Imprensa Nacional, 1902. v. 7.

CaIro, Luis Roberto Velloso. Santiago Nunes Ribeiro e o Minerva Brasiliense. Letras de Hoje, Porto Alegre, v. 31, n. 4, p. 41-51, 1996.

Caldeira, Claudia Adriana Alves. Francisco de Paula Brito: política e imprensa. Revista Maracanã, Rio de Janeiro, v. 8, n. 8, p. 113-127, 2012.

CÂmara, P. Perestrelo da. Coleção de provérbios, adágios, rifões anexins, sentenças morais e idiotismos da língua portuguesa. Rio de Janeiro: Eduardo \& Henrique Laemmert, 1848 .

Carvalho, José Murilo de. A construção da ordem: a elite política imperial. O teatro das sombras. 3. ed. Rio de Janeiro: Civilização Brasileira, 2007.

Correio Mercantil. Instrutivo, político, universal. Rio de Janeiro. 1852

Chartier, Roger. Cardenio entre Cervantes e Shakespeare. A história de uma peça perdida. Rio de Janeiro: Civilização Brasileira, 2012.

Diário do Rio de JANEIRo. Rio de Janeiro, 1843.

Furtado, João Pinto. O manto de Penélope: história, mito e memória da Inconfidência Mineira de 1788-9. Companhia das Letras: São Paulo, 2002.

FurTADO, Joaci Perreira. Uma república de leitores. História e memória na recepção das Cartas Chilenas (1845-1989). São Paulo: Hucitec, 1997.

GAMA, Miguel do Sacramento Lopes. Lições de eloquência nacional. Rio de Janeiro: Tipografia de Francisco de Paula Brito, 1846. v. 1.

Hansen, João Adolfo. Prefácio. In. Furtado, Joaci Perreira. Uma república de leitores. História e memória na recepção das Cartas Chilenas (1845-1989). São Paulo: Hucitec, 1997.

Hansen, João Adolfo. A sátira e o engenho: Gregório de Matos e a Bahia do século XVII. 2. ed. São Paulo: Ateliê; Campinas: Editora da Unicamp, 2004.

Hodgart, Matthew. Satire. Origins and principles. New Jersey: Transaction Publishers, 2009.

LAPA, Manoel Rodrigues. Cartas chilenas. Tomás Antônio Gonzaga. Edição crítica de M. Rodrigues Lapa. Rio de Janeiro: Instituto Nacional do Livro, 1957. 
LAUSBerg, Heinrich. Elementos de retórica literária. 2. ed. Lisboa: Fundação Calouste Gulbenkian, 1972.

Lima, José Inácio Abreu e. Sinopse ou dedução cronológica dos factos mais notáveis da história do Brasil. Recife: Tipografia de M. M. Faria, 1845.

Luvizotto, Caroline Kraus. Cultura gaúcha e separatismo no Rio Grande do Sul. On-line. São Paulo: Editora UNESP; Cultura Acadêmica, 2009. Disponível em: https://goo.gl/i1vZ7X

Maxwell, Kenneth. A devassa da devassa. A Inconfidência Mineira: Brasil e Portugal (1750-1808). Rio de Janeiro: Paz e Terra, 2009.

Mckenzie, Donald Francia. Bibliography and the sociology of texts. In: Mckenzie, Donald Francia. Bibliography and the sociology of texts. Cambridge: Cambridge University Press, 2004.

Minerva Brasiliense Biblioteca Brasílica. Rio de Janeiro, 1845a. n. 8.

Minerva Brasiliense Biblioteca Brasílica. Rio de Janeiro, 1845b. n. 12.

Moraes, Alexandre Jose de Mello. Corografia histórica, cronográfica, genealógica, nobiliária e política do Império do Brasil (1858-1860). Rio de janeiro: Tipografia Brasileira, 1858. Tomo III.

Pesavento, Sandra Jatahy. A revolução farroupilha. São Paulo: Brasiliense, 2003.

Proença Filho, Domício (Org.). A poesia dos Inconfidentes: poesia completa de Cláudio Manuel da Costa, Tomás Antônio Gonzaga e Alvarenga Peixoto. Rio de Janeiro: Nova Aguilar, 1996.

ReIs, Sérgio Ricardo Magalhães. Casa de Correção da Corte: verso e anverso de um projeto de ordem e civilização. Dissertação (Mestrado em História Política) Universidade do Estado do Rio de Janeiro, Rio de Janeiro, 2005.

Schwartz, Lilia Moritz. As barbas do Imperador. D. Pedro II, um monarca nos trópicos. 2. ed. São Paulo: Companhia das Letras, 2004.

Silva, Joaquim Norberto de Sousa e. Dirceu de Marília. Liras atribuídas à Senhora DMJD de S (Natural de Vila Rica). Rio de Janeiro: Fundação Biblioteca Nacional, s/d. Disponível em: http://objdigital.bn.br/Acervo_Digital/Livros_eletronicos/ dirceu_de_marilia.pdf

Teixeira, Ivan. Mecenato pombalino e poesia neoclássica. Basílio da Gama e a poética do encômio. São Paulo: Edusp, 1999.

Villalta, Luiz Carlos. Reformismo ilustrado, censura e práticas de leitura: Usos do livro na América Portuguesa. São Paulo: FFLCH, 1999. 
Recebido em 21 de agosto de 2018.

Aprovado em 19 de novembro de 2018.

\section{Resumo/Abstract/Resumen}

\section{As "Cartas Chilenas" do jornal Minerva Brasiliense e a murmuração da Corte no Segundo Reinado}

\section{Socorro de Fátima Pacífico Barbosa}

Este trabalho é resultado de uma pesquisa - e seus desdobramentos - que teve início em 2007. A pesquisa tem como objeto e fonte primária os jornais e periódicos luso-brasileiros dos séculos XVIII e XIX e se fundamenta teóricometodologicamente na História Cultural. Esta pesquisa considera que os periódicos não são apenas "arquivos" onde se publicaram os "clássicos" da literatura, mas condição determinante para a criação e a consolidação de alguns gêneros literários, o que implica em tomar este suporte como responsável tanto pela economia interna da linguagem, como pela divulgação e circulação da cultura escrita do 19 (McKenzIE, 2004). Ademais, observa-se, nestes anos de pesquisa desenvolvida diretamente nos periódicos, que aos jornais e aos autores dos séculos XVIII até meados do XIX eram alheias algumas noções que embasaram e fomentaram as compilações e estudos sobre as Cartas Chilenas desde 1863, quando da sua primeira publicação em livro. Nasce aí a pergunta que sempre acompanhou esta sátira: "Quem é o autor"? Trata-se de uma abordagem da literatura e dos escritos literários baseados na individualização da escrita, na originalidade das obras e na canonização do autor, que não suportava a angústia de uma obra não ter um autor que lhe corresponda (Chartier, 2012). Assim, tal qual fez-se e comprovou-se que a Epístola a Critilo não é obra de Tomás Antonio Gonzaga, mas uma publicação satírica publicada no fornal Científico, Econômico, e Literário, ou Coleção de Várias Peças, Memórias, Relações, Viagens, Poesias, e Anedota (1826), cujo alvo são os desmandos de D. Pedro I (BARBosA, 2013), este trabalho demonstrará como a sátira As Cartas Chilenas deve ser compreendido como um escrito de 1845, publicado no periódico $M i$ nerva Brasiliense, cuja temática corresponde à murmuração do corpo imperial, sobretudo aquele que se desenvolvia como atos discursivos nos jornais e periódicos de 1845 contra algumas decisões de D. Pedro II desde sua ascensão ao trono, através do Golpe da Maioridade ao perdão aos participantes da Revolução Farroupilha.

Palavras-chave: "Cartas Chilenas", Minerva Brasiliense, Santiago Nunes Ribeiro, Sátira. 
The "Cartas chilenas"of the newspaper Minerva Brasiliense and the murmuring of the Court in the Brazilian Second Reign

\section{Socorro de Fátima Pacífico Barbosa}

This work is the result of a research - and its unfolding - that began in 2007. The research has as object and primary source the Luso-Brazilian periodicals and periodicals of the XVIII and XIX centuries and is based theoretically and methodologically in Cultural History. This research considers that journals are not only "archives"where the "classics" of the literature have been published, but a determining condition for the creation and consolidation of some literary genres, which implies taking this support as responsible both for the internal economy of the language, as by the dissemination and circulation of the written culture of 19 (McKenzIE, 2004). Moreover, there is, in these years of research conducted directly in the papers, that the newspapers and the authors of the eighteenth century until the mid-nineteenth were others some ideas that supported and promoted compilations and studies on the Chilean Letters since 1863, when its first book publication. The question arises that always followed this satire: "Who is the author"? It is an approach to literature and literary writings based on the individualization of writing, the originality of the works and the canonization of the author, who could not bear the anguish of a work without having a corresponding author (CHARTIER, 2012). So, as it was made and it was shown that the Epístola a Critilo is not the work of Tomás Antonio Gonzaga, but a satirical publication published in the fornal Científico, Econômico, e Literário, ou Coleção de Várias Peças, Memórias, Relações, Viagens, Poesias, e Anedota (1826), which target the excesses of D. Pedro I (BARBosA, 2013), this paper will demonstrate how satire Cartas chilenas should be understood as a written 1845, published in the journal Minerva Brasiliense, whose theme corresponds to the murmuring of the Imperial Court, especially the one that developed as discursive acts in the newspapers and periodicals of 1845 against some decisions of D. Pedro II from his ascension to the throne, through the Coup of the Majority to the pardon to the participants of the Farroupilha Revolution.

Keywords: "Cartas Chilenas", Minerva Brasiliense, Santiago Nunes Ribeiro, Satire.

\section{Las "Cartas Chilenas"del diario Minerva Brasiliense y la murmuración de la Corte en el Segundo Reinado}

\section{Socorro de Fátima Pacífico Barbosa}

Este trabajo es el resultado de una investigación - y sus desdoblamientos - que empezó en 2007. La investigación tiene como objeto y fuente primaria las revistas y periódicos luso-brasileños de los siglos XVIII y XIX. Se fundamenta teórica y metodológicamente en la Historia Cultural. Esta investigación considera que 
los periódicos no son solo "archivos"donde se publicaron los "clásicos"de la literatura, sino condición determinante para la creación y la consolidación de algunos géneros literarios, lo que implica tomar este soporte como responsable tanto por la economía interna del lenguaje, como por la divulgación y circulación de la cultura escrita del siglo XIX (McKENZIE, 2004). Además, se observa en estos años de investigación desarrollada directamente en los periódicos, que los diarios y autores de los siglos XVIII y mediados del XIX eran ajenos a algunas de las nociones que sirvieron de base y fomentaron las compilaciones y estudios sobre las "Cartas Chilenas"desde 1863, cuando fueron publicadas en libro. Nace ahí la pregunta que siempre acompañó esta sátira: ¿quién es el autor? Se trata de un abordaje de la literatura y de los escritos literarios basados en la individualización de la escritura, en la originalidad de las obras y en la canonización del autor, que no soportaba la angustia de que una obra no tuviese su autor correspondiente (CHARTIER, 2012). Así se comprobó que la Epístola a Critilo no es obra de Tomás Antonio Gonzaga, sino una publicación satírica publicada en el fornal Científico, Econômico, $e$ Literário, ou Coleção de Várias Peças, Memórias, Relações, Viagens, Poesias, e Anedota (1826), cuyo objetivo son los desmanes de D. Pedro I (BArbosa, 2013). Este trabajo demostrará como la sátira As Cartas Chilenas debe ser entendida como un escrito de 1845 publicado en el periódico Minerva Brasiliense, cuya temática se corresponde con las murmuraciones sobre el cuerpo imperial, sobre todo aquello que se desarrollaba como actos discursivos en los diarios y periódicos de 1845 contra algunas decisiones de D. Pedro II desde su ascensión al trono, desde el Golpe de la Mayoridad al perdón a los participantes de la Revolución Farroupilha.

Palabras clave: "Cartas Chilenas", Minerva Brasiliense, Santiago Nunes Ribeiro, Sátira. 